\title{
A PLACEBO ALKALMAZÁSÁNAK ETIKAI VONATKOZÁSAI
}

\author{
BODNÁR VIVIEN ${ }^{1}$ - BÁRDOS GYÖRGY² \\ ${ }^{1}$ ELTE PPK Pszichológiai Intézet, Pszichológiai Doktori Iskola \\ ${ }^{2}$ ELTE PPK Egészségfejlesztési és Sporttudományi Intézet \\ E-mail: bardosgy@gmail.com
}

Beérkezett: 2017. március 23. - Elfogadva: 2017. július 4.

\begin{abstract}
Jelen tanulmány a placebo terápiás és klinikai kutatásokban történö felhasználásának etikai kérdéseit veszi sorra, külön hangsúlyt helyezve a megtévesztés, az egészségügyi hátrány, a kutatási torzítás és a teljes körü tájékoztatás kérdéskörére. Az összefoglaló kitér a terápiás és klinikai hatásvizsgálatok során alkalmazott gyakorlati placebófelhasználás jellemzöire, összefoglalva a téma kurrens irodalmát, külön hangsúllyal a Köteles és munkatársai (2007) összefoglalóját kö̈vetô, szakterületet érintố fejleményekre és kutatási eredményekre. A 20. századot követôen a farmakocentrikus orvostudomány, föleg az etikai kérdésfelvetés mentén, a placebót negatívnak bélyegezte, ezen bélyeg pedig begyúrüzött a gyógyítás makrokontextusába, befolyásolva és nehezitve a placebo hatékony felhasználását a betegségek gyógyításában, az öngyógyító mechanizmusok elôsegitésében és a tünetek enyhitésében. Napjainkra azonban a placebo témakörében végzett kutatások egyértelmú eredményeinek köszönhetôen egyrészról a placebo felhasználását vitató kérdés fókusza a „lehet-e” kérdésról a „szabad-e” kérdésre módosult, az etikai megfontolások mentén pedig a fókusz tovább változik, immár nem a „szabad-e”, hanem a „hogyan kell alkalmazni” válik releváns kérdéssé.
\end{abstract}

Kulcsszavak: placebo, etika, terápiás felhasználás, megtévesztés 


\section{BEVEZETÉS}

A placebo szó a latin placere (= tetszeni) igébôl származik, jelentése „tetszeni fogok”. A placebo szót a köznyelvben azokra az anyagokra használják, amelyek semmilyen hatóanyagot nem tartalmaznak, mégis gyógyító hatásúak. A jelenséget többen többféleképpen definiálták, egyesek szúkebb értelemben, kizárólag az orvostudományhoz kapcsoltan (Hornung, 1994), mások (pl. Shapiro és Shapiro, 1997; Ross és Olson, 1981; Brody, 2000) tágabban, a specifikus, farmakológiai, biológiai alapú, „valódi” és a nem specifikus, pszichológiai eredetû, „nem valódi” fókusz mentén értelmezik a jelenséget (Köteles, 2014).

A placebo hatásmechanizmusa úgynevezett top-down folyamaton alapul: pszichológiai vonatkozásokkal együttesen értelmezhetô, mely magában foglalja a kulturális közeget, a normákat, a szemantikus és epizodikus emlékezetet és a gyógyító-beteg közötti interperszonális kapcsolat sajátosságait is (Gold és Lichtenberg, 2014).

Annak ellenére, hogy a placebo alkalmazása mind pszichológus (Magyar Pszichológiai Társaság, 2004), mind pedig orvosetikai (Magyar Orvosi Kamara, 2012; American Medical Association, 1847) szempontból több kérdést is felvet, hatásossága megkérdôjelezhetetlen, és számos vizsgálat által bizonyított. „A placebóval való gyógyítás legfontosabb kérdése tehát már egy ideje nem az, hogy lehetséges-e, hanem hogy szabad-e" (Köteles és mtsai, 2007, 430).

\section{A MEGTÉVESZTÉS PROBLEMATIKÁJA}

\section{A megtévesztés dilemmái}

Szabad megtéveszteni a beteget? Szabad-e hamis információkkal ellátni a pácienst, vagy esetleg hazudni neki, annak tudatában, hogy a placebo hatásossága (látszólag) a megtévesztés függvényében alakul. A hazugság a Révai nagylexikon definíciója alapján „annyi, mint tudva, akár szóval, akár csak valami jellel, másnak megtévesztése céljából annak az ellenkezôjét mondani, amit igaznak tudunk”, illetve „aki másban szándékosan, ha nem is határozott szavak segítségével, de jellel, kétértelmúséggel, tartózkodással stb., olyan véleményt kelt, mely azzal, amit igaznak tud és tart, ellenkezik, ugyancsak hazudik". Amikor tehát orvos-beteg viszonyban az orvos által felírt placebót követốn a beteg azt gondolhatja a szerról, hogy az aktív hatóanyagot tartalmaz, miközben placebo; vagy csupán elhallgat információkat, építve arra, hogy a placebohatás része a „teljes gyógyszerhatásnak” (Claridge, 1970), akkor megtéveszti a beteget, ha tetszik „kegyesen hazudik”. A „Mentiris ut medicus” vagyis „úgy hazudik, mint egy orvos" jelenség sokáig jellemezte az orvos-beteg kapcsolat paternalisztikus modelljét, amelyben az orvos maga sem rendelkezett sokáig a betegségek megfelelô tudományos magyarázatával, a gyógyulás érdekében pedig nem tájékoztatta megfelelóen a pácienst sem. A 20. századtól kezdôdôen azonban, megkérdôjelezve a korábbi modellt, a megtévesztéssel járó placeboterápiát mind az orvos, mind pedig a beteg oldaláról a biomedikális orvoslás elítélte, a megtévesztésbôl, az autonóm, felelős terápiaválasztás- 
hoz, illetve döntéshez szükséges információk visszatartásából eredő erkölcsi hátrányt, az emberi méltóság megsértését helyezve elôtérbe. A helyzet azonban közel sem fekete-fehér, a placebohasználat során felmerülő megtévesztés komplex kérdés, hiszen nem minden hazugság esik azonos erkölcsi megítélés alá, arról nem is beszélve, hogy a placebohatáshoz nem feltétlenül szükséges a megtévesztés.

A beteg érdekében történő „kegyes” hazugság méregfogát igyekszik kihúzni a placebo nyílt alkalmazása: például a doktor azt mondja a betegnek, hogy „Felírok önnek egy kapszulát, amely az előzetes vizsgálatok alapján segíthet. Jelen körülmények között hiszem azt, hogy enyhíteni fogja a tüneteit minimális mellékhatással számolva”. Az empirikus bizonyítékoknak köszönhetốen tehát az orvos az általa hatásosnak vélt, aktív hatóanyagot nem tartalmazó placebót ír fel annak érdekében, hogy a beteg állapota javuljon, a felírt szer konkrét hatásmechanizmusának részletes leírása pedig - abban az esetben, ha erre külön nyíltan megfogalmazott kérés/kérdés nem érkezik a beteg részérôl - csupán mellékes információ, annak ismertetése a paternalizmus csapdájába esésével fenyeget. A beteg ugyan korábbi tapasztalataira alapozva úgy gondolhatja, hogy valódi gyógyszert kapott, miközben placebót írt fel az orvos, illetve a beteg autonómiájának megórzése szempontjából szükséges volna a tájékoztatás és az esszenciális információk megosztása, az azonban vitatandó, hogy mi minôsül esszenciálisnak (Gold és Lichtenberg, 2014). A megtévesztés problematikája tehát továbbra is fennáll, még a legjóhiszemúbb alkalmazás is megtévesztéssel jár.

A felhasználás többségét jellemzó, megtévesztéssel járó placebofelhasználásról sokan sokféleképpen vélekednek (Köteles és mtsi, 2007). A deontológiai álláspont („köteles, kötelesség") a szabályok, etikai alapelvek követését vallja, vagyis a megtévesztést mindenféle körülmények között elítéli, és az álláspont követôi a placebo alkalmazását csak a legvégsóbb esetben tartják elfogadhatónak, akkor is csak szigorú szabályoknak való megfelelés esetén. A cselekvés helyes voltát elsôsorban a morális szabályok betartása határozza meg, a következményektôl függetlenül. Az utilitárius/teleológiai álláspont („hasznos”) ennél sokkal megengedôbb, amely a lehetô legnagyobb mértékú boldogság elérését tartja szem előtt, vagyis a cselekvés helyességét a következmények alapján ítéli meg, az alapján, hogy a betegnek és a köznek mi a legjobb, vagyis „a cél szentesíti az eszközt, tehát amennyiben az orvos szerint a placeboterápia használ a betegnek, akkor a megtévesztés elfogadható” (Köteles, 2012). Ugyanezen álláspont keretei között azonban a panaszok enyhülése, mint rövid távú haszon, együtt járhat hosszú távon megjelenô károkkal, mint a beteg, illetve akár az egész társadalom bizalmának megrendülése az orvoslás intézményében, amely logika mentén az alkalmazás elvetendô (Bostick, 2008).

Foddy (2011) meghatározott keretek között elfogadhatónak tartja a megtévesztés alkalmazását a placeboterápiákban, lévén, hogy bizonyos tünetek, illetve nem diagnosztizálható panaszok esetén a placebo képes a tünetek enyhítésére. A beteg pedig avval, hogy felkeresi orvosát, explicite, illetve implicite kifejezi, hogy a tünetek enyhítését várja tôle. Annak érdekében tehát, hogy az orvos placebóval segíthessen a betegen, a megtévesztés a Helsinki Nyilatkozattal (1964) összhangban elfogadható, amennyiben nem áll rendelkezésre más, bizonyítottan hatásos terápia, ha a doktor világosan kifejezi, hogy a kezelés csupán a tünetek enyhítését célozza, nem pedig a probléma esetleges gyökereinek kezelésére szolgál; illetve elkerülvén a paternalisztikusság bélyegét, az orvos mindig a beteg érdekeit szem eloótt tartva alkalmazza csupán a megtévesztést. 
Megtévesztés-e a megtévesztés - avagy a betegek valóban megtévesztve érzik-e magukat?

Köteles és Ferentzi (2012) kutatásai alapján a betegek számára a terápia eredményessége, vagyis a gyógyulás fontosabb, mint az, hogy történt-e megtévesztés, a placebohatás eléréséhez pedig szükséges bizonyos mértékú megtévesztés, a „cél tehát szentesíti az eszközt.” Amennyiben pedig a terápia hatásos volt, és a betegek késôbb teljes körú tájékoztatást kapnak, akkor az orvos-beteg bizalom sem rendül meg.

Kisaalita és munkatársai (2012) vizsgálatában a betegek $80 \%$-a elfogadhatónak találta a placebohasználatot, különösen, ha ebból a betegnek elônye származott, az ó kérésére történt az alkalmazás, illetve nem volt más alternatív terápia elérhetô. Elutasították azonban az alkalmazást abban az esetben, ha létezett más sztenderd terápia, vagy hatására a tünetek romlottak. A fájdalom kezelése esetén a placebohasználat elfogadott, ha teljes körú a tájékoztatás, hatásosnak bizonyul a terápia, és nem progresszív fájdalomról van szó (Savvas és mtsai, 2014). Érdemes tehát észrevenni, hogy az etikai megítélésben az utóbbi idôben egyre nagyobb hangsúlyt kap nemcsak a beteg, hanem az orvos érdeke is, és érdekes új megközelítést ígér az, ha a beteg és az orvos érdekeit egyszerre kielégítô megoldások kerülnek a kutatások célkeresztjébe.

\section{AZ EGÉSZSÉGI HÁTRÁNY ÉS A KUTATÁSI TORZÍTÁS KÉRDÉSEI}

Az elméleti problémák boncolgatását követôen a gyakorlati alkalmazás további kérdéskörét jelenti a terápiás kezelésben, illetve a hatásvizsgálatok során a placebót kapó betegek esetleges egészségi hátránya, amely aggály rendezésére a Helsinki Nyilatkozat (1964) egyebek (pl. módszertani okok) mellett kimondja, hogy akkor ajánlott a placebo terápiás használata, „amennyiben nem áll rendelkezésre más, bizonyítottan hatásos terápia”.

Mégis, a gyógyszercégek az új szerek hatásosságának vizsgálatakor gyakran, más korábban bizonyítottan hatásos terápia helyett placebokontrollt használnak, megsértve evvel a Helsinki Nyilatkozatot (1964). Az Amerikai Egyesült Államokban a gyógyszerek engedélyeztetése a „Code of Federal Regulation” alatt múködô Food and Drug Adminsitration" (FDA)-n keresztül lehetséges, ez utóbbi pedig a placebokontroll-vizsgálatokat a szerek hatásosságának egyik fơ mércéjének tekinti. Ez annak ellenére is így van, hogy mára világossá vált, hogy a kontrollcsoportba tartozó betegek így valóságos és elkerülhetônek tûnô - hátrányt szenvednek azzal, hogy elesnek a bizonyítottan hatásos terápiától. Ez nem csupán a betegek jogait tekintve aggályos, hanem a tudomány szempontjából is megkérdôjelezhetô. Egy új terápiát hatásosnak ítélni annak alapján, hogy hatásosabb, mint a placebo, ahelyett, hogy egy már bizonyítottan hatásos terápiához mérnénk, elsôsorban a gyógyszercégek érdekeit szolgálja. A terápiák komplex jellegét figyelmen kívül hagyja a kizárólag a placebót mércének használó megközelítés, illetve illuzórikus tudományos eredményt jelent a placebóval való összehasonlítás következtében „felpumpált” szignifikancia és hatásméret (Rothman és Michels, 1994). Különösen így van ez annak ismeretében, hogy a placebocsoport önmagában nem elégséges kontroll, szükség van (illetve volna) egy kezeletlen kontrollcsoportra is (észlelt vs. valódi placebohatás), ami módszertani okokból nem mindig valósítható meg. 
A Fázis 3 randomizált farmakológiai kontrollvizsgálatokra (továbbiakban: RCT) jellemzô placeboaktív kezelés - nincs kezelés feltételekkel jellemezhetô vizsgálatok esetében a kezelést nem kapó csoport tagjai, azon túl, hogy - etikailag megkérdôjelezhetô módon - elesnek egy létezô terápiától, így tüneteik, és problémáik „a tudomány érdekében” nem enyhítôdnek, hajlamosak kilépni a vizsgálatból, vagy a vizsgálat mellett más aktív gyógymódot keresni, amely erôsen torzíthatja az eredményeket (Porzsolt és mtsai, 2004).

Shellings és munkatársai (2006) szisztematikus áttekintésükben az ilyen háromágú RCT-k különbözô formáinak, vagyis az úgynevezett „single-consent” (amikor a kísérleti csoport felvilágosítást kap a saját kezelésérôl), az „incomplete-double-consent” (minden résztvevôt informálnak a saját kezelésükről) és a „complete-double-consent” (amikor minden résztvevô mindenki kezelésérôl kap információt) etikai kérdéseit vitatják. A Zelen (1977) által támogatott randomizált „single-consent design” esetében a résztvevôk a tájékoztatást megelôzôen kísérleti, illetve kontrollcsoportba kerülnek besorolásra, a kontrollcsoportba tartozók mindenféle tájékoztatás nélkül a legjobb sztenderd terápiát kapják. Az elrendezésnek köszönhetôen azonban a kontrollcsoport tagjai nincsenek is tudatában annak, hogy egy vizsgálatban vesznek részt, a tájékoztatás hiánya etikailag erôsen megkérdőjelezhetô. Jellemzốn a vizsgálatok többsége az etikailag is elfogadottabb „double-consent design”-nal jellemezhető.

Enck és munkatársai (2013) a fenti problémák megoldására a klinikai gyógyszervizsgálatokban a placebohatás minimalizálását, míg a kezelések során annak maximalizálását javasolják. Utóbbi elérése a körültekintôen megfogalmazott tájékoztatáson keresztül a betegek elvárásainak befolyásolásával, a kondicionált placeboválasz kiváltásával, a meleg és empátiával jellemezhetô orvos-beteg viszonnyal, és a placeboterápia személyre szabásával lehetséges.

A klinikai vizsgálatokban, kísérletekben tehát nem kevésbé problémás a placebo alkalmazása, mint a kezelések esetén, hiszen alapvetô tétel, hogy az egyén nem szenvedhet hátrányt a közösség érdekében, így senkitôl sem vonható meg a létezô leghatásosabb terápia. Kutatási szempontból azonban kulcsfontosságú, hogy legyen ilyen csoport, azaz a résztvevôk véletlenszerûen kerüljenek a különböző feltételekbe és csoportokba. A problémát a véletlenszerú csoportba sorolást megelôzô teljes körú tájékoztatás, a tudományosan értékes kutatások, a valid adatok és a résztevók tisztelete és vizsgálatból való visszalépési jogának biztosítása segítségével igyekeznek feloldani a szakemberek.

A terápiás kezelés esetében a kutatások során felmerült aggályok mellett további kérdések árnyalják a placebo felhasználásának lehetôségeit. A terápiába való részvételhez szükséges az informált beleegyezés, vagyis hogy a beteg egyéniesített formában információkat kapjon a kezelés folyamatáról, előnyeirôl, hátrányairól, kereteirôl és a lehetséges alternatívákról. Ugyanakkor a placebohatás lényegi eleme a megtévesztés, aminek alkalmazása nehezen értelmezhetô az elóbbiekben említett tájékoztatás keretei között (Bíró és Varga, 2013).

Kiemelendô azonban, hogy a legetikusabbnak vélt teljes körú tájékoztatásnak vannak veszélyei is. Amikor a betegek a felelôs döntéshez széles körú tájékoztatást kapnak az adott szer mellékhatásairól és veszélyeirôl, számos esetben elôfordul, hogy a tájékoztatás hatására a placebocsoport tagjainak egy része is a szerre jellemzô/jellem- 
zônek vélt mellékhatásokat kezdi produkálni. A betegtájékoztatók nyelvezete, megfogalmazása rendszerint inkább a gyógyszercégek és kórházak, mint a betegek érdekeit védik jogi szempontból (Loftus és Fries, 2008). Az ún. „nocebóhatás” a negatív elvárások megvalósulását jelenti, a placebokörülmények között tapasztalt mellékhatások öszszességét, azokat a jelenségeket, amikor a placebo hatása károsító. Végsô soron tehát az információtöbblet útján történô védekezésért komoly árat kell fizetnünk (Köteles és Bárdos, 2012).

Létezik azonban tájékoztatás iatrogén károkozás nélkül is. A megfogalmazás, a hangsúlyok, a pozitív szuggesztiók (Diószeghy, 2000; Varga, 2007), az objektív információ validan pozitív köntösbe való becsomagolása egy bizalmi orvos-beteg viszonyban a beteg érdekeit szolgálják, öngyógyító mechanizmusainak elôsegítését teszik lehetôvé anélkül, hogy a döntéshez szükséges információkhoz való hozzáférést korlátoznák, vagy negatív értelemben vett megtévesztést alkalmaznának (Varga, 2001; 2008; 2011). A betegtájékoztatók esetében célszerúbb volna egy általános, nem túl részletes tájékoztató, mely magában foglalja a placebohatás magyarázatát is (Loftus és Fries, 2008).

\section{TÖRTÉNIK VALÓJÁBAN?}

\section{A placebo gyakorlati alkalmazása}

A gyakorlatban a háziorvosok széleskörúen alkalmaznak placebót. A megkérdezett magyar háziorvosok 83\%-a használt már placebót a praxisában, 25\%-uk hord magánál aktív placebo tablettákat, és saját placeboalkalmazásukat $(6,0 \%)$ alacsonyabbra becsülik, mint kollégáikét $(9,8 \%)$. Többségük úgy vélekedik, hogy adott körülmények között a placebohasználat indokolt, és mindössze 1,8\%-uk vélekedett úgy, hogy a placebo felhasználását be kellene tiltani (Ferentzi és mtsai, 2011).

Az aktív, „impure” placebo (leggyakrabban vitaminok, vírusfertőzések esetén antibiotikumok, illetve analgetikumok) használata gyakoribb, mint a „pure” placebóké (sóinjekció, cukorkapszulák és placebotabletták), utóbbi inkább a háziorvosok körében, míg elôbbi a kórházakban népszerú. Fassler és munkatársai (2010) szisztematikus áttekintése (22 tanulmány 12 országból) alapján az orvosok 17-80\%-ban, a nóvérek pedig 51-100\% közötti arányban alkalmaztak „tiszta” placebót munkájuk során, 73\%-uk azonban úgy gondolja, hogy alkalmazásával megtévesztik a beteget. 45\%-uk ezen okból elutasítja a placebót, 50\%-uk azonban úgy találja, hogy a hatásosság legitimálhatja a használatot. Linde és munkatársai (2014) németországi vizsgálatukban úgy találták, hogy a háziorvosok 35\%-a, a belgyógyászok 12\%-a, míg az ortopédusok 9\%-a alkalmazott placebót a vizsgálatot megelôzó 12 hónapban.

\section{Müködik a placebohatás megtévesztés nélkül is?}

Számos korai és modern vizsgálat mutatta ki a metaplacebok hatásosságát, vagyis azt, hogy placebohatás létrejöhet megtévesztés nélkül is. Spiro (1998) B $_{12}$ vitamin és meg- 
felelően megfogalmazott instrukciók segítségével enyhítette páciensei ismeretlen eredetû fájdalmát. Kaptchuk és munkatársai (2010) irritábilis bélszindróma esetén találták hatékonynak az úgynevezett „open-label”, vagyis megtévesztést nem feltételezô placebót az IBS-tünetek enyhítésében és gyógyulásban, Kelley és munkatársai (2012) pedig major depressziós betegek kezelésében alkalmaztak sikeresen, a betegtájékoztatás teljes körú tiszteletben tartása mellett placebót.

Annak ellenére tehát, hogy a placebók alkalmazásához leggyakrabban megtévesztést használnak, a hatás megjelenhet e nélkül is, a legfớbb prediktor pedig az orvosbeteg kapcsolat minôsége lesz. Az akár megtévesztés nélkül megjelenô placebohatást többféle faktor befolyásolja, többek között a makro- és mikrokontextus, az orvos, a beteg és a gyógyszer jellemzôi, illetve ezek interakciója (Köteles, 2012). A hitnek bizonyított egészségügyi következményei vannak, így ha ebben a kapcsolatban a beteg tud hinni a gyógyulásban, az orvos pedig verbális és nonverbális kommunikációjával azt közvetíti, hogy gyógyulást vár, akkor ôszinte tájékoztatás mellett is múködhet a placebo.

\section{KITEKINTÉS}

A placebo felhasználása hosszú századokra nyúlik vissza, mi több, a modern kori orvoslást megelôzóen a gyógyítás elsôsorban placebókra támaszkodhatott (Shapiro és Shapiro, 1997). A 20. századot követôen azonban az orvostudomány, fôleg az etikai kérdésfelvetés mentén, a placebót negatívnak bélyegezte, és széles körben elterjedt a placebót mind a betegek, mind pedig az orvosok szempontjából pejoratív köntösbe bújtató elképzelés, miszerint a placeboreakció csupán a fejben létezik, alkalmazása sérti az emberi méltósághoz és az önálló döntéshez fưzôdó jogot. A problémafelvetés azonban munkára és a placebo gyógyításban betöltött szerepének kutatására sarkallta a szakembereket, a kutatások egyértelmú eredményei pedig a kérdés fókuszát a „lehet-e” kérdésrôl a „szabad-e” kérdésre terelték. Az etikai megfontolások mentén pedig a kérdés fókusza tovább változik, immár nem a „szabad-e”, hanem a „hogyan kell alkalmazni” a releváns kérdés.

A placeboterápiának, bizonyos esetekben, a farmakoterápiával összemérhetô a hatásossága, és számos további probléma esetén alkalmas a tünetek és panaszok enyhítésére, a páciens szubjektív és objektív jólétének elósegítésére; hatalmas elônye pedig, hogy a hagyományos orvoslás eszköztárával összehasonlítva szinte alig terhelik a szervezetet, a mellékhatások megjelenésének valószínúsége jóval kisebb. Annak ellenére, hogy önálló terápiás alkalmazásának is van létjogosultsága, az alternatív és komplementer módon történô felhasználása kétségkívül hatékony és alkalmazandó (Köteles, 2012). A kondicionálásos megközelítés keretei között például a krónikus terápiák esetén a hosszan tartó gyógyszerterhelés csökkentése érdekében a placebo és a hatóanyagot tartalmazó szer váltakozó alkalmazása elôsegítheti a mellékhatások csökkenését a szer által indukált biológiai folyamatok fenntartása mellett.

Az emberi szervezet rendkívül komplex, a regeneráció, vagyis a szervezet öngyógyító mechanizmusai számos területen, mint például az immunrendszer, a sejtszintú múködések vagy a viselkedésszervezés, tetten érhetốek. Az orvostudomány célja a re- 
generációhoz szükséges optimális körülmények megteremtése, és a szervezet egészséges állapotba történô visszajuttatása. A placeboválasz az öngyógyító folyamatok által meghatározott, ilyenformán pedig az orvostudomány céljának nem a placebóreakció ignorálása és leválasztása kellene lennie, hanem a kiváltásához szükséges optimális körülmények garantálása.

A cél tehát egyértelmú, a gyakorlat azonban más. A klinikai gyógyszervizsgálatok során a placebohatás többnyire csupán az összehasonlítás alapját adja, ahelyett, hogy az adott szer nem specifikus, teljes mértékben kiaknázandó és maximalizálandó elemeként tekintenénk rá. A gyógyszerekben található aktív hatóanyagok mellett a mikro- és makrokontextus számos más tényezője határozza meg a teljes gyógyszerhatást (Claridge, 1970; Helman, 2001). Amennyiben elfogadhatjuk alaptételnek, hogy az orvostudomány és a gyógyszercégek célja a betegek meggyógyítása, a regeneráció elôsegítése, de legalább a tüneteik enyhítése, akkor a placebohatás napjainkra jellemzó ilyen mérvú figyelmen kívül hagyásával a gyógyító orvostudomány egy fontos és hatékony módszertôl fosztja meg magát.

A kutatásoknak tehát a kiszúrés helyett a nem-specifikus hatások maximalizálást kellene célul kitûzniük, azonosítva a placebohatás olyan nem-specifikus elemeinek jellemzôit, mint a placeboreaktív személyiség, az optimális gyógyító kontextus, a szerek sajátosságai, az orvos személyiségjellemzói, az orvos-beteg kapcsolat és a mikrokontextusban megjelenó szuggesztiók jellemzôi.

A gyógyítás hatékonyságát tovább növelné a makrokontextus, vagyis a kulturális környezet, az egészségrôl-betegségrôl, illetve placebóról kialakított közvélekedés további változása, a pejoratív sztereotípia lerombolása. A placebohatást vizsgáló kutatásoknak az etikai dilemmákat tárgyaló értekezéseknek köszönhetôen elindultunk a beteg gyógyulását szem elōtt tartó rögös úton. A viták fontosak, a válaszok és megoldások komplexitásához járulnak hozzá, a célhoz vezetô út pedig sokféle lehet, a cél azonban örök: a gyógyítás elôsegítése. Végsố soron - mindezek mellett - a placebohatás mechanizmusának felderítése kiemelkedô fontosságú volna: ennek ismeretében ugyanis a kívánt hatás talán placebo alkalmazása nélkül is elérhetô volna. Ezzel pedig a placeboetika kérdésköre okafogyottá válna...

\section{IRODALOM}

American Medical Association (1847). Code of Medical Ethics. Letöltve: 2017.06.13-án: https:/ / www.ama-assn.org/sites/default/files/media-browser/public/ethics/1847code_0.pdf

Az Orvos-világszövetség Helsinki deklarációja (1964). Letöltve: 2017.04.20-án: https://ett.aeek. hu/wp-content/uploads/2016/09/helsinki_hu.pdf

Bíró E., \& Varga K. (2013). A betegtájékoztatás dilemmái. Szuggesztív hatások egészségügyi vonatkozásai kurzus, ELTE PPK, 2013.09.26.

Bostick, N. A., Sade, R., Levine, A. M., \& Steward, M. D. Jr. (2008). Placebo use in clinical practice: report of the American Medical Association Council on Ethical and Judical Affairs. The Journal of Clinical Ethics, 19(1), 58-61.

Brody, H. (2000). The Placebo Response. New York: Harper Collins.

Claridge, G. (1970). Drugs and Human Behaviour. New York and Washington: Praeger Publishers. 
Cziboly Á., \& Bárdos Gy. (2003). A placebo fogalma, története, alkalmazása, valamint számos magyarázó elméletének áttekintése. Magyar Pszichológiai Szemle, 58(3), 381-416.

Diószeghy Cs., Varga K., Fejes K., \& Pénzes I. (2000). Pozitív szuggesztiók alkalmazása az orvosi gyakorlatban: tapasztalatok az intenzív osztályon. Orvosi Hetilap, 141(19), 1009-1013.

Enck, P., Bingel, U., Schedlowski, M., \& Rief, W. (2013). The placebo response in medicine: minimize, maximize or personalize? Nature Reviews, 12, 191-204.

Fassler, M., Meissner, K., Schneider, A., \& Klaus, L. (2010). Frequency and circumstances of placebo use in clinical practice- a systematic review of empirical studies. BMC Medicine, $8(15)$.

Ferentzi, E., Köteles, F., \& Bárdos, Gy. (2011). The use of placebos in medical practice. A questionnaire survey among GPs of Hungary. Original Papers, 5, 73-84.

Foddy, B. (2011). The ethical placebo. The Journal of Mind-Body Regulation, 1(2), 53-62.

Gold, A., \& Lichtenberg, P. (2014). The moral case for the clinical placebo. Medical Ethics, 40, 219-224.

Helman, C. G. (2001). Placebos and nocebos: the cultural construction of belief. In D. Peters (Ed.), Understanding the Placebo Effect in Complementary Medicine (pp. 3-16). Edinburgh: Churchill Livingstone.

Hornung, J. (1994). Was ist ein placebo? Die Bedeutung einer korrekten Definition für die klinische Forschung. Fortschritte der Komplementarmedizin, 1, 160-165.

Kaptchuk, T. J., Friedlander, E., Kelley, J. M., Sanchez, M. N., Kokkotou, E., Singer, J. P. et al. (2010). Placebos without deception: A randomized controlled trial in irritable bowel syndrome. Plos ONE, 5(12), 1-7.

Kelley, J. M., Kaptchuk, T. J., Cusin, C., Lipkin, S., \& Fava, M. (2012). Open-label placebo for major depressive disorder: a pilot randomized controlled trial. Psychotherapy and Psychosomatics, 81(5), 312-314.

Kisaalita, N. R., \& Robinson, M. E. (2012). Analgesic placebo treatment perceptions: acceptability, efficacy, and knowledge. The Journal of Pain: Official Journal of the American Pain Society, 12, 920-928.

Köteles F., \& Bárdos Gy. (2012). Placebo és nocebohatás a gyógyításban. In Urbán R., Demetrovics Zs., Rigó A., \& Oláh A. (szerk.), Az egészségpszichológia elmélete és alkalmazása II. (pp. 153-204). Budapest: ELTE Eötvös Kiadó.

Köteles F. (2012). Placebo. Az egészségpszichológia alapkérdései és társadalmi kontextusa kurzus, meghívott elóadó, ELTE PPK, 2012.11.05.

Köteles, F., \& Ferentzi, E. (2012). Ethical aspects of clinical placebo use: What do laypeople think? Evaluation $\mathcal{E}$ the Health Professions, 35(4) 462-476.

Köteles F., Fodor D., Cziboly Á., \& Bárdos Gy. (2007). A placebo terápiás felhasználásának etikai kérdései. Magyar Pszichológiai Szemle, 62(4), 429-448.

Köteles F. (2014). A placebo-válasz. Budapest: Medicina Kiadó.

Linde, K., Friedrichs, C., Alscher, A., Wagenpfeil, S., Meissner, K., \& Schneider, A. (2014). The use of placebo and non-specific therapies and their relation to basic professional attitudes and the use of complementary therapies among German physicians- a cross-sectional survey. PloS ONE, 9(4).

Loftus, F. E., \& Fries, F. J. (2008). The potential perils of informed consent. Focus Review, 11(2), 217-218.

Magyar Pszichológiai Társaság (2004). Pszichológusok szakmai etikai kódexe (SzEK). Budapest. Letöltve: 2017. 06.13-án: http:/ /szemegpszich.elte.hu/wp-content/uploads/2012/04/ Etikai-K\%C3\%B3dex.pdf

Magyar Orvosi Kamara (2012). A Magyar Orvosi Kamara Etikai kódexe. Letöltve: 2017.06.13-án: http://aok.pte.hu/docs/dekan/file/ekodex.pdf 
Porzsolt, F., Schlotz-Gorton, N., Biller-Andorno, N., Thim, A., Meissner, K., Roeckl-Wiedmann, I. et al (2004). Appyling evidence to support ethical decisions: Is the placebo really powerless? Science and Engineering Ethics, 10(1), 119-132.

Révai J. M., Kovács Z., \& Sziklay J. (1911). Révai Nagy Lexikona, az ismeretek enciklopédiája. Budapest: Révai Testvérek Irodalmi Intézet Részvénytársaság.

Ross, M., \& Olson, J. M. (1981). An expectancy-attribution model of the effects of placebos. Psychological Review, 88, 408-437.

Rothman, K. J., \& Michels, K. B. (1994). Sounding board. The continuing unethical use of placebo controls. The New England Journal of Medicine, 331(6), 394-398.

Savvas, S. M., Zelencich, L. M., \& Gibson, S. J. (2014). Should placebo be used routinely for chronic pain in older people? Maturitas, 79(4), 389-400.

Shapiro, A. K., \& Shapiro, E. (1997). The Powerful Placebo. From Ancient Priest to Modern Psychican. Baltimore: Johns Hopkins University Press.

Shellings, R., Kessels, A. G., Riet, G., Knottnerus, J. A., \& Sturmans, F. (2006). Randomized consent design in randomized controlled trials: Systematic literature search. Contemporary Clinical Trials, 27, 320-332.

Spiro, H. M. (1998). The Power of Hope: A Doctor's Perspective. New Haven and London: Yale University Press.

Varga K., \& Diószeghy Cs. (2001). Hütésbefizetés, avagy a szuggesztiók szerepe a mindennapi orvosi gyakorlatban. Budapest: Pólya Kiadó.

Varga K. (szerk.) (2008). Szuggesztív kommunikáció a szomatikus orvoslásban. Budapest: VL Sugár Bt.

Varga K. (2011). A szavakon túl: Kommunikáció és szuggesztió az orvosi gyakorlatban. Budapest: Medicina Könyvkiadó.

Varga, K., Diószeghy, Cs., \& Fritúz, G. (2007). Suggestive communication with the ventilated patient. European Journal of Mental Health, 2, 137-147.

Waber, R. L., Shiv, B., Carmon, Z., \& Ariely, D. (2008). Commercial features of placebo and therapeutic efficacy. The Journal of the American Medical Association, 299(9), 1016-1017.

Zelen, M. (1977). Statistical options in clinical trials. Seminars in Oncology, 4, 441-446.

\section{THE ETHICAL ASPECTS OF GIVING PLACEBOS}

\section{BODNÁR, VIVIEN - BÁRDOS, GYÖRGY}

The present study reviews the ethical aspects of using placebos in therapy and clinical studies with special emphasis on the topics of deception, health risk, research bias and informed consent. This summary discusses also the characteristics of the practical use of placebo in therapy and clinical efficacy studies.

After the 20th century, the pharmaco-centric medicine, mainly referring to the ethical aspects, stigmatised the term of placebo, and this stigma - through affecting our macro context - influenced and reduced the effective use of placebo in curing diseases, promoting self-healing mechanisms and relieving symptoms.

Nowadays, however, thanks to the clear results of placebo studies, the focus of the question of using placebos changed from "is it possible?" to "is it permitted?", and, along with the ethical considerations, the focus will continue to change, so instead of "is it permitted?" the question of "how to apply?" may become relevant.

Keywords: placebo, ethics, therapy, deception, clinical trials 